\title{
FINANCIAL LEVERAGE DECISIONS IN AN ERA OF CORPORATE EARNINGS DOWN-TURN AND FINANCIAL MARKET INSTABILITY - THE NIGERIAN EXPERIENCE
}

\author{
Abel \& Ezeoha* \\ Rhodes University, South Africa \\ aezeoha@yahoo.co.uk
}

July 2011

\begin{abstract}
This paper examines the impact of profitability on the financial leverage of firms operating in an unstable macroeconomic environment such as Nigeria. Using fixed and dynamic panel models, it finds consistent evidence that the profitability of a firm significantly and negatively affects its short-term debt, but not its long-term debt capital. It attributes this to the unstable nature of the Nigerian business environment and the relative inefficiency of its financial markets. It signals that Nigerian firms could be over-relying on short-term debt and external equity to fund long-term investments - a trend that is capable of increasing cost of capital to a level above any plausible limit.
\end{abstract}

Keywords

Firms, financial leverage, profitability, instability, theory, Nigeria

* $\operatorname{Dr}$ AE Ezeoha is a post-doctoral fellow in the Department of Economics and Economic History, Rhodes University, Grahamstown, South Africa. 


\section{INTRODUCTION}

Internal equity is the cheapest source of corporate finance, and its availability is dependent on a firm's performance. Profitable firms that have a strong internal equity base make less use of external debt, with its attendant stringent cost and risk implications (Arnold, 1998; Baskin, 1989). According to the prediction of the pecking order theory, the individual capital structures of firms reflect historical profitability and growth rather than a predetermined optimal mix of equity and debt (Erickson \& Trevino, 1994). On the contrary, firms that that face cash-flow difficulties are likely to rely more on debt financing. According to the "earnings downturn" hypothesis, borrowing to ease financial frictions caused by macroeconomic instability can exacerbate agency and cash-flow problems that are associated with management decisions leading to a situation where managers might be borrowing to finance non-viable (negative net present value) projects (Hansen \& Cutchley, 1990). This not only brings about depletion of the value of the affected firm, but also exposes the firm to higher risk of bankruptcy.

Just as short-fall in operating income can cause a firm to rely more on debt financing, inefficient financial markets also can constrain the firm's access to external finances, especially in developing countries (Demirguc-Kunt \& Maksimovic, 1996; Stein, 1997). This study therefore investigates the impact of profitability on the financial leverage of firms operating in an unstable macroeconomic environment such as Nigeria. The choice of Nigeria as a case in point here is based on the fact the country has since the late 1980s been faced with numerous financial market crises, leading to the failure of about 32 banks between 1990 and 2004 (Ezeoha, 2007). Inflation and lending rates also averaged as much as $24.5 \%$ and $24.6 \%$, respectively, between 1990 and 2005 (Ezeoha \& Amaeshi, 2010), and, as shown in Figure 1, the average earnings ratio of most of the listed non-financial firms was as low as $-2.1 \%$ in 1999 . Our study contributes to empirical literature on corporate financial management by contextualising the acclaimed effect of profitability using the case of listed non-financial firms in Nigeria, and by testing the consistency of this effect using both fixed and dynamic panel models. It finds results consistent with both fixed and dynamic panel models that the profitability of a firm is negatively and significantly related to total debt ratio.

\section{REVIEW OF THE PROFITABILITY-LEVERAGE DEBATE}

In the literature, a relationship between corporate earnings and financial leverage has been argued along the propositions of both the pecking order and the trade-off theories. The pecking order theory predicts that debt ratio typically grows only when the financial needs of a firm exceed the firm's internal capital base and vice versa. Since internal capital is mostly raised from retained profits, it follows that more profitable firms should have lower debt ratios. On the other hand, low-profit, high-investment-opportunity firms should have higher debt and ultimately issue more equity than high-profit, low-investment-opportunity firms (Cosh \& Hughes, 1994; Arnold, 1998). Essentially, by enhancing the market power and internal equity base of a firm, profitability plays one of the key roles in corporate financial management (Pandey, 2004).

Among the earliest proponents of the pecking order theory are Donaldson (1961) and Myers and Majluf (1984). The original assumption of the theory, according to Myers and Majluf, is that companies prefer to finance their projects from internally generated cash-flows, and that when this source of financing is exhausted, they move on to debt, and only when also debt is not 
sufficient to fill financing needs, additional equity is issued. King and Ross (1993) emphasise that as much as $80 \%$ of financing of firms is done with internally generated funds.

Unlike the pecking order theory, the trade-off theory postulates that the debt-equity mix of a firm is not a cumulative result of hierarchical financing decisions over time, but represents instead a well-defined optimal capital structure that is aimed at balancing the benefits of debt financing with the associated risks of bankruptcy (Shyam-Sunder \& Myers, 1999). Based on the trade-off theory, profitability is expected to have positive effect on leverage given that most profitable firms would prefer to use more debts so as to benefit from the tax-shield advantage (Gaud, Jani, Hoesli \& Bender, 2005). The conflicting predictions of the two theories form the basis for the contradictions inherent in the results of previous studies. Highlighting this contradiction, Barclay and Smith (2005), for instance, argue that the pecking order theory is incapable of explaining the full array of financial policy choices available to a firm, and that even when a firm generates surpluses arising from improved financial performance, the decision by the firm as to whether or not to adjust its capital structure will still depend on the level of transaction and adverse selection costs. Firms with high transaction and adverse selection costs for equity than for debt should then be expected to preserve higher debt capacity for future financing by adjusting in favour of equity or internal capital.

Another criticism of the pecking order theory is that firms can maintain a systematic order of financing only in those environments where access to both the internal and the external markets for funds is relatively easier. Demirguc-Kunt and Maksimovic (1996), for instance, demonstrate that the high costs of diversification inherent in an economy that lacks a stock market may induce firms to avoid the use of financial markets; and also that the absence of a wellfunctioning stock market leads to a situation where firms are unable to structure their financing packages optimally. In this situation, firms may be forced to rely on available sources, irrespective of the risk implications of doing so. Such expected reaction is consistent with the argument of Stein (1997) that in a credit-constrained economy, where not all positive NPV projects can be financed, headquarters create value by actively reallocating scarce funds across projects.

Empirically, there is a large body of evidence that demonstrates the importance of corporate performance for financial decisions. Mako (2001) shows that the combination of corporate debt and equity is strongly linked to performance, because cash-flow from a firm's operations is the major source of servicing corporate debts. This relationship has also been investigated by Fama and French (2002), Hansen and Crutchley (1990), Baskin (1989), Toy, Stonehill, Remmers, Wright and Beekhuisen (1974), and others. The results of these studies generally confirm that the relationship between profitability and leverage is significantly negative across most classes of firms. The studies find evidence strongly in support of the pecking order theory based on the claim that debt ratios are positively linked to growth opportunities and negatively linked to profitability. Similarly, the implication of pecking order behaviour is also stressed by Erickson and Trevino (1994), who demonstrate that the individual capital structures of firms will reflect historical profitability and growth rather than a predetermined optimal mix of debt-equity. Using a cross-section of data from very large firms, Baskin (1989) also shows that firms that have higher accumulated internally generated revenue tend to borrow less, while those operating in the higher growth industries tend to have more loans in their portfolios.

Interestingly, studies conducted in developed economies and those in developing economies seem to produce similar results. For developed economies, Titman and Wessels (1988) specifically use 469 US firms, from 1974 to 1982 , to establish that profitability as a determinant 
of capital structure is negatively related to all the measures of leverage, including long-term and short-term debt to market value of equity ratios. In the case of the United Kingdom, Bevan and Danbolt (2002) investigate the dynamic nature of capital structure and its determinants for listed UK companies over the period 1991 to 1997 , and find that the effect of profitability on leverage is also systematically negative and highly statistically significant.

Among studies in developing economies, Baral (2004), for instance, investigates the determinants of capital structure among 40 listed Nepalese companies that cut across several economic sectors. He finds that profitability, corporate size, and growth rate play a major role in determining the financial leverage in corporate institutions - explaining about $72 \%$ of changes in financial leverage. Using 208 Malaysian companies, Pandey (2004) similarly concludes that profitability, business risk, growth opportunities, and ownership have negative and significant effects on total debt ratio. Booth, Aivazian, Demirguc-Kunt and Maksimovic (2001) investigate capital structures of firms in 10 developing countries, with Zimbabwe as the only African country on the list. Their cross-sectional estimation model reveals that the variables that are relevant for explaining capital structures in developed countries are also relevant in the case of developing countries, despite differences in institutional factors. Contrary to the results of other studies, Booth et al. show that profitable firms tend to use more debt to lower their tax liabilities, that the tangibility of assets affects total and long-term debt decisions differently, and that the impact of business risk on leverage varied across countries. For their part, Gwatidzo and 0jah (2009) make use of fixed-effects and random-effects panel models to empirically compare capital structure determinants in five African countries (Ghana, Kenya, Nigeria, South Africa, and Zimbabwe). They find that of all the countries, it is only in Kenya and Zimbabwe that profitability does not have any significant impact on leverage. In the case of Nigeria, the results show that profitability has a positive effect on both total debt and long-term debt, but a nonsignificant negative effect on short-term debt. This is unlike the case of South Africa, where the coefficient of profitability is found to be negative and significant for both total debt and shortterm debt, but positive and non-significant for long-term debt. Similar results are found in the case of Ghana, except that the effect on long-term debt is negative and non-significant at the conventional $5 \%$ level.

To the best of the author's knowledge, there is no comprehensive evidence available on how financial leverage reacts to firms' income patterns in an economic environment where corporate income flows are highly irregular and where the financial markets are relatively incapable of meeting the financing needs of firms. The study by Gwatidzo and 0jah (2009), which is cited above, in the case of Nigeria involves a shorter panel of 62 listed companies over the period 1999-2003. It is possible that both the size of the panel and the methodology adopted could have influenced the conclusion they each on the effect of profitability on leverage. In addition to extending the size of the panel to cover about 71 listed firms over a longer period 1990-2006, our own study also uses both fixed and dynamic panel models to test the stability of the profitability-leverage relationship over time.

\section{THE RESEARCH DATA AND ECONOMETRIC MODEL}

\subsection{Variable definition}

In this paper, financial leverage constitutes the dependent variable under investigation, while profitability is the major independent variable. We control for profitability, asset tangibility, 
growth opportunities, firm size, and business risk, which are considered by previous studies to be among the most important capital structure determinants.

\subsubsection{Financial Leverage}

Previous studies generally measure financial leverage in terms of both book value and market value of debts (see for instance Chakraborty, 2010; Frank \& Goyal, 2009; Guad, Jani, Hoesli \& Bender, 2005; Fama \& French, 2002; Booth et al., 2001). However, it is usually difficult to estimate the market value of assets of firms operating in most parts of Africa due to the unavailability of data. Three proxies measuring financial leverage are therefore constructed using the book-value approach. Justifications for the choice of the book value measures can also be found in Mackie-Mason (1990), Ferri and Jones (1979), and more specifically in Fama and French (2002), who postulate that most predictions under the trade-off and pecking order theories apply more directly to book value leverage than to market value leverage. Following Chen (2004), the three proxies are defined as follows: (1) total debt ratio - equals the ratio of the book value of total debt to total assets; (2) short-term debt ratio - equals the ratio of the book value of short-term debt to total assets; and (3) long-term debt ratio-equals the ratio of the book value of long-term debt to total assets.

\subsubsection{Profitability}

Following Pandey (2004), Dittmar (2004), Schoubben and Van Hulle (2004), profitability is defined as the ratio of earnings before interest and $\operatorname{tax}(\varepsilon B I T)$ to total assets. As has been highlighted above, the effect of profitability on leverage depends on the theoretical standpoint under consideration and on the maturity of debt instruments. The pecking order theory predicts a negative effect (Gomes, 2001; Pandey, 2004; Fama \& French 2002), but the trade-off theory predicts a positive effect (Chen, 2004). There is also some empirical evidence positing that firms may follow a pecking order in the short term even though a long-term target policy exists (Guad, et al., 2005). This implies that the effect of profitability on leverage may be negative in the short run but positive in the long run.

\subsubsection{Control variables}

\subsubsection{Growth opportunity}

The analytical model includes growth opportunity because of the prediction that growth firms follow an order of financing that places internal capital first and long-term external equity last. According to Myers (1977), growth opportunity should negatively impact on leverage because growth firms are also likely to invest sub-optimally, leading to situations where creditors become reluctant to lend for long horizons. A more conventional measure of growth opportunity is the ratio of R\&D and advertisement expenditures to sales. However, due to the problem of data availability, an alternative proxy is adopted (ratio of average sales growth to total asset growth), as recommended by Chen (2004).

\subsubsection{Business risk}

Business risk is defined as the volatility of operating income - that is, percentage change in operating income over time. This has been used by previous researchers to explain why lenders usually discriminate against certain kinds of industry. Allen (1991) argues that firms in the same industry may experience similar levels of business risk and face the same trends in earnings variability. As in Gaud et al. (2005), it is expected that a negative relationship between business risk and financial leverage exists. 


\subsubsection{Asset tangibility}

A strong fixed asset and inventory base gives a firm the level of collateral value required to attract external finances. Braun and Larrain (2005) argue that in a world with incomplete financial contractibility, having assets that are easily transferable improves a firm's access to external funding. Based on the prediction of the trade-off theory and the empirical results from Rajan and Zingales (1995) and Frank and Goyal (2009), a positive relationship between asset tangibility and financial leverage is expected. In line with Huang and Song (2006), as well as Chakraborty (2010), the ratio of fixed assets to total assets is used as a proxy for asset tangibility.

\subsubsection{Firm size}

Following Ferri and Jones (1979), Booth et al. (2001) and Pandey (2004), firm size is defined as the natural logarithm of turnover. The impact of firm size on leverage depends on the level of financial market development in an economy, thus explaining why its effect could vary between developed and developing economies (Chakraborty, 2010). Again, whereas the pecking order theory predicts a negative relationship between size and leverage, the trade-off theory predicts a positive relationship. In line with the findings of Bevan and Danbolt (2002) and given the dominance of short-term debt financing among listed Nigerian firms, a negative relationship is expected.

\subsection{Data and descriptive statistics}

The data used in the study consists of annualised panel data series sourced directly from the financial reports of 71 non-financial companies, for the period 1990-2006, as well as from the Nigerian Stock Exchange Fact-Book on the performance and profiles of listed companies in Nigeria. The two sources are authoritative and more accessible, given that micro data on the performance of Nigerian companies, especially for the earlier years, is not available in international databases such as Thomson DataStream.

As at year-end 2006, there were a total of 208 quoted companies. Of this number, there were 139 non-financial companies, 22 banks, 28 insurance companies, 16 second-tier or privately placed firms, and three managed funds. Financial firms were excluded from our sample because their balance sheets are usually very different from those of non-financial firms. Also, privately placed firms are excluded because of the difficulty in accessing their financial data. The remaining 139 firms are therefore made up of those in the industrial, commercial and nonfinancial services sectors in Nigeria.

The 2006 Nigerian Stock Exchange annual Fact-Book confirmed that about 68 out of the 139 listed non-financial firms were unable to supply their audited annual financial reports, for the periods 2000 to 2006, to the Exchange as stipulated in the Companies and Allied Matters Act of 1990. A total of 68 firms were therefore dropped from the sample because including them would have resulted in missing observations for most parts of the period 2000-2006. The final sample of 71 firms provided estimates on financial leverage and the independent variables for the periods 1990-2006, with few gaps in the resulting panel dataset.

Summary statistics on the profitability ratio of the sampled firms indicate some unique patterns over the period 1990-2006. As can be observed in Figure 1, for the sub-samples, the first period (1990-1995) can be classified as the period of relative stability, with average earnings ratios ranging from $11.2 \%$ to $18.2 \%$. The second period (1996-2000) recorded a relative decline in 
average earnings ratios ranging from $-2.1 \%$ to $7.2 \%$. On the other hand, 2001-2006 was characterised by relative fluctuations in earnings.

Table 1 compares the summary statistics across these three major periods - earnings stability (1990-1995), earnings downturn (1996-2000), and earnings fluctuation (2001-2006). All three measures of financial leverage (total debt, short-term debt and long-term debt) recorded similar patterns both for the full sample (1990-2006) and for the periods identified above. Total debt ratio averaged 0.622 for the whole sample, 0.623 for the period $1990-1995,0.637$ for 1996 2000 , and 0.61 for 2001-2006.

Both short-term and long-term debt measures followed a similar pattern, with short-term debts constituting up to $90 \%$ of total debt financing across the three periods. As expected, profitability was highest during the period 1990-1995, and lowest during 1996-2000.

TABLE 1: Summary statistics for the debt ratios, profitability and the control variables across different earnings periods

\begin{tabular}{|c|c|c|c|c|c|c|c|c|}
\hline & \multicolumn{2}{|c|}{$1990-2006$} & \multicolumn{2}{|c|}{$1990-1995$} & \multicolumn{2}{|c|}{$1996-2000$} & \multicolumn{2}{|c|}{$2001-2006$} \\
\hline & Mean & S.D & Mean & $S . D$ & Mean & $S . D$ & Mean & S.D \\
\hline Total Debt & 0.622 & 0.378 & 0.623 & 0.332 & 0.637 & 0.471 & 0.610 & 0.333 \\
\hline $\begin{array}{l}\text { Short-term } \\
\text { Debt }\end{array}$ & 0.567 & 0.353 & 0.565 & 0.317 & 0.576 & 0.423 & 0.561 & 0.322 \\
\hline $\begin{array}{l}\text { Long-term } \\
\text { Debt }\end{array}$ & 0.055 & 0.122 & 0.060 & 0.128 & 0.059 & 0.122 & 0.049 & 0.117 \\
\hline Profitability & 0.091 & 0.220 & 0.096 & 0.188 & 0.083 & 0.249 & 0.093 & 0.221 \\
\hline Tangibility & 0.344 & 0.202 & 0.335 & 0.207 & 0.349 & 0.201 & 0.347 & 0.200 \\
\hline Growth Opport. & -171.32 & 6513.83 & 102.479 & 606.697 & -605.05 & 11330.0 & 0.169 & 1340.88 \\
\hline Size & 3.018 & 0.879 & 3.009 & 0.863 & 3.004 & 0.897 & 3.035 & 0.921 \\
\hline Risk & 2.129 & 3.658 & 2.335 & 3.788 & 2.328 & 3.643 & 1.839 & 3.561 \\
\hline No. of Obsv. & \multicolumn{2}{|c|}{1207} & \multicolumn{2}{|c|}{426} & \multicolumn{2}{|c|}{355} & \multicolumn{2}{|c|}{426} \\
\hline
\end{tabular}

Source: Author's calculation based on data from the financial statements of the sampled firms

It is important to point out the differences in the number of observations per variable. Due to a few missing observations, the number of observations recorded for all three of the financial leverage proxies is 1125 , that of the profitability variable is 1127 , size variable is 1145 , and tangibility is 1 124. The least number of observations is recorded for the business risk (1 109) and growth opportunity ( 1068 ). The reduction in the number of observations for business risk and growth opportunities is based on the methodological definitions adopted in the process of constructing the two variables. 


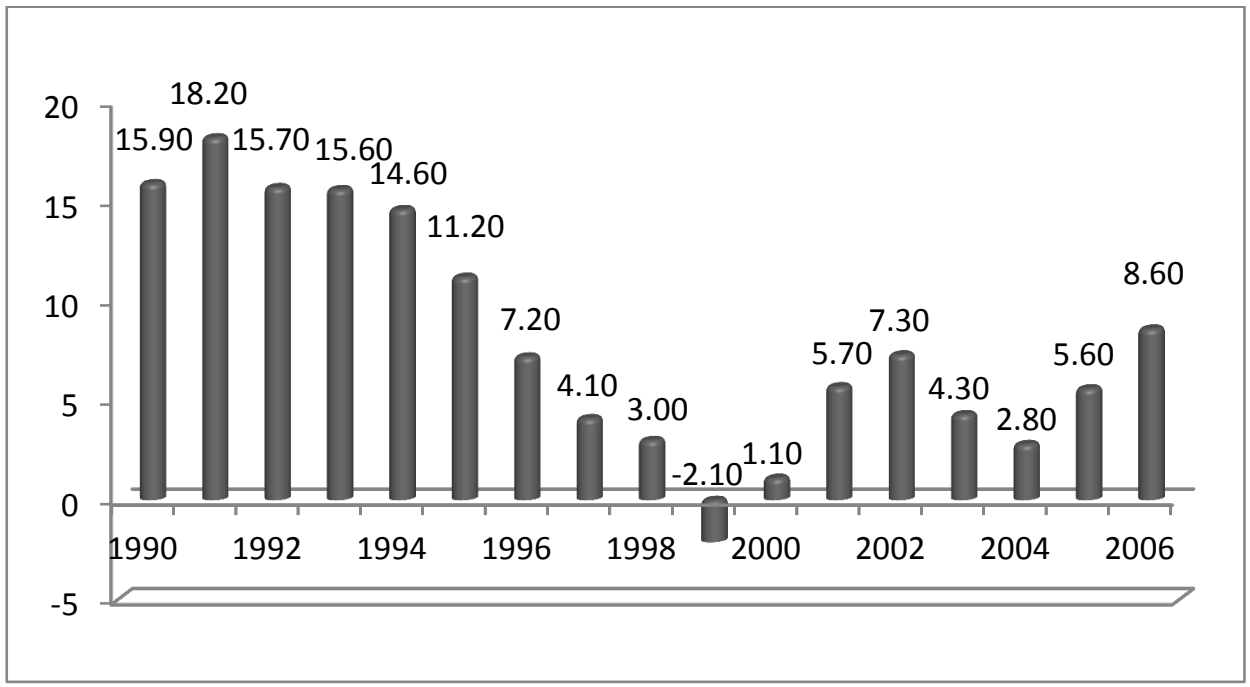

FIGURE 1: Trends in average earnings to total asset ratios (1990-2006)

Source: Author's calculation based on data from the financial statements of the sampled firms

Table 2 reports the correlation coefficient for each pair of the variables. Short-term debt ratio is highly correlated with total debt ratio, with a coefficient of 0.944 . Also, long-term debt is strongly correlated with total debt (correlation coefficient is 0.284 ).

TABLE 2: Pearson Correlation Coefficients between the dependent and the independent variables

\begin{tabular}{|c|c|c|c|c|c|c|c|c|c|c|}
\hline Variables & & 1 & 2 & 3 & 4 & 5 & 6 & 7 & 8 & VIF \\
\hline Total Debt & 1 & 1.000 & & & & & & & & \\
\hline $\begin{array}{l}\text { Short-term } \\
\text { Debt }\end{array}$ & 2 & 0.944 & 1.000 & & & & & & & \\
\hline $\begin{array}{l}\text { Long-term } \\
\text { Debt }\end{array}$ & 3 & 0.284 & -0.041 & 1.000 & & & & & & \\
\hline Profitability & 4 & -0.323 & -0.337 & -0.007 & 1.000 & & & & & 1.05 \\
\hline Tangibility & 5 & 0.002 & -0.074 & 0.221 & -0.165 & 1.000 & & & & 1.04 \\
\hline $\begin{array}{l}\text { Growth } \\
\text { Opport. }\end{array}$ & 6 & -0.015 & -0.022 & 0.015 & -0.027 & -0.066 & 1.000 & & & 1.01 \\
\hline Size & 7 & 0.095 & 0.083 & 0.059 & 0.080 & -0.023 & -0.059 & 1.000 & & 1.01 \\
\hline Risk & 8 & -0.054 & -0.057 & -0.004 & 0.018 & -0.090 & 0.038 & 0.009 & 1.000 & 1.01 \\
\hline
\end{tabular}

In line with the prediction of the pecking order theory, profitability is negatively correlated with the three leverage measures, though the level is strong only for total debt and short-term debt measures (coefficients are -0.323 and -0.337 , respectively). Consistent with the trade-off theory, long-term debt is positively and strongly correlated with tangibility (coefficient is 
0.221 ), but negatively correlated with profitability (coefficient is -0.165 ). Between the other independent variables, the levels of correlation do not seem to be very significant, as none of the coefficients is up to 0.10 . This gives an impression that multicollinearity might not be a problem in our estimation model. However, to test further for multicollinearity, we carried out a variance inflation factor (VIF) test, which showed that none of the results of the VIF test is above the conventional benchmark of 10 , suggesting that multicollinearity does not pose a serious threat in the estimation model (Chakraborty, 2010).

\subsection{Estimation model}

Panel estimation of the hypothesised relationship between financial leverage and profitability (and the control variables) is considered using both fixed and dynamic panel models. The fixed effects model applied in this study is expressed as follows:

$$
\text { Leverage }_{i t}=\alpha_{0}+\beta \text { Profit }_{i t}+\phi\left(\text { Tangible }_{i t}, \text { Size }_{i t}, \text { Growth }_{i t}, \operatorname{Risk}_{i t}\right)+\eta_{i}+u_{i t}(\mathbf{1})
$$

where $\beta$ and $\Phi$ are vectors of coefficients associated with the exogenous and control variables, respectively, $\eta_{i}$ is the time-invariant firm-specific random variable, and $\mu_{i t}$ is the random error heteroskedastic term.

For the estimates from equation one to be considered consistent and unbiased, the major conditions that must be satisfied are: that $\mu_{\mathrm{it}}$ is uncorrelated with $v$; that the coefficients $\beta$ and $\Phi$ have a zero mean and constant variance $\sigma_{n}^{2}$; and that $v_{t}$ is independently distributed across individual firms, with a variance $\sigma_{\alpha}^{2}$. Unfortunately due to the likelihood of some causality between the left-hand-side variable and the right-hand-side variables, as well as between the independent variables and the disturbance term, the above conditions are most times difficult to attain. A possible way of resolving this problem is to use a simultaneous equation technique, where the causality problems and simultaneity bias can be eliminated by using the two-stage least-squares estimation technique (2SLS) and finding appropriate instruments for the exogenous variables which are correlated neither with any of the right-hand-side variables nor with the random-error heteroskedastic term. Again, in most corporate finance studies, it has been reported that finding such reliable instruments can be very difficult (Flannery and Hankins, 2010). It is this position that makes the dynamic panel model an emerging and significant approach in recent capital structure studies. Its strength lies in the fact that, rather than focusing on weak instruments, it optimally exploits all the linear moment restrictions specified by the model (Antoniou, Guney \& Paudyal, 2008), and also allows for robust inference of lagged dependent variables in the presence of unobserved heterogeneity (Arellano \& Bond, 1991; Huynh \& Petrunia, 2010).

Bearing in mind that non-random panel estimation techniques have fallen out of favour in recent studies on capital structure determinants (e.g. Chakraborty, 2010; 0zkan, 2001), the analysis is therefore extended by adopting the two-step system-generalised methods of moment (GMM) introduced by Arellano and Bover (1995), and extended by Blundell and Bond (1998). This model uses the differencing as in the difference-GMM plus the lagged exogenous variables' first differences as instruments in an equation of the level-variables.

Again, given also that capital structure decisions are a dynamic, rather than constant, process (see for instance, Ozkan, 2001; Baker \& Wurgler, 2002; Gaud et al., 2005), we integrate a firm's readiness to adjust its leverage towards a target into equation (1). The speed of adjustment, according to de Miguel and Pindado (2001) is, however, dependent on the level of transaction 
costs, with the adjustment process moving towards actual leverage ratio as follows:

$$
\text { Leverage }_{i t}=\alpha \text { Leverage }_{i t}^{*}+(1-\alpha) \text { Leverage }_{i t-1} \quad 0<\alpha<1
$$

where Leverage $e_{i t}$ is the actual leverage ratio, Leverage ${ }_{i t}^{\star}$ is the target debt ratio, $\alpha_{i}$ is a measure of transaction cost with value between 0 and 1 , and Leverage $e_{i t-1}$ is the preceding year's leverage ratio. Combining equations (1) and (2) into a dynamic model, therefore, gives rise to equation (3), with

$$
\begin{aligned}
& \text { Leverage }_{i t}=\alpha_{0}+f\left(\text { Leverage }_{i t-1}, \text { Profit }_{i t}, \text { Tangible }_{i t}, \text { Size }_{i t}, \text { Growth }_{i t}, \text { Risk }_{i t}+\right. \\
& \eta_{i}+v_{t}+u_{i t}
\end{aligned}
$$

where $\eta_{i}$ is the unobserved firm-specific effects, capturing unobservable characteristics of the firm that have a significant effect on firm's leverage, and $\eta_{t}$ is the time specific effects, capturing the effects of those factors that are the same for all firms in a given year but vary across time.

\section{RESULTS AND DISCUSSION}

\subsection{Panel fixed effects estimation}

A Hausman diagnosis test (Hausman, 1978) was carried out to show that panel fixed effects estimates are more robust that those of random effects panel estimates. The fixed effects estimates on the relationship between financial leverage and profitability are reported in Table 3. Models 1,2 and 3 contain estimates based on equation 1 with total debt ratio, shortterm debt ratio and long-term debt ratio as the respective dependent variable. For models 1 and 2 , profitability is negatively significant at the $1 \%$ level, but for model 3 it is positive and slightly significant at the $10 \%$ level. The results seem to provide support for the pecking order theory, and are consistent with the findings of earlier studies, especially those that made use of total debt ratio as the proxy for financial leverage (Frank \& Goyal, 2009; Ozkan, 2001).

For the control variables, results from models 1 and 2 are quite similar. Although the coefficients appear with the expected signs, very few of variables seem to have significant effects on leverage, based on a fixed effects model. The coefficient of tangibility (defined as the ratio of fixed assets to total assets) in model 3 is positive and significant at the $1 \%$ level, which confirms the predictions of the trade-off theory. Also consistent with the findings of previous studies, the risk variable (measured as annual percentage change in operating income) has negative and significant effect in models 1 and 2 . Size is found to have a negative and significant effect only in model 3, which confirms the findings by Rajan and Zingales (1995) in the case of German firms, and Titman and Wessels (1988). In all of the models the coefficient of the lagged leverage variable is negative and highly significant at the $1 \%$ level. This implies that a firm's debt burden is inversely related to its ability to access the external debt market.

\subsection{Dynamic system - GMM Estimation}

As mentioned earlier, the panel fixed effects estimation can be biased because of the likelihood of some simultaneity bias. Thus, it is expected that a dynamic model should render a more accurate account of the relationship between corporate profitability and financial leverage also in the Nigerian context. Table 4 reposts the results of the system-GMM model based on equation 
(3) and the advice of Arellano and Bover (1995) and Blundell and Bond (1998).

TABLE 3: Panel fixed effects estimation results

\begin{tabular}{|c|c|c|c|}
\hline & $\begin{array}{l}\text { Total Debt } \\
\text { (1) }\end{array}$ & $\begin{array}{c}\text { Short-term Debt } \\
\text { (2) }\end{array}$ & $\begin{array}{c}\text { Long-term Debt } \\
\text { (3) }\end{array}$ \\
\hline \multicolumn{4}{|l|}{ Variable } \\
\hline Leverage & $-0.210 * \star \star(0.038)$ & $-0.215 * \star \star(0.036)$ & $-0.187 * \star \star(0.034)$ \\
\hline Profitability & $-0.530 \star \star \star(0.058)$ & $-0.532 \star \star \star(0.050)$ & $0.035 *(0.020)$ \\
\hline Tangibility & $-0.026(0.069)$ & $-0.101 *(0.060)$ & $0.092 \star \star \star(0.024)$ \\
\hline Growth Opport. & $-0.001(0.001)$ & $-0.001 *(0.001)$ & $0.001(0.001)$ \\
\hline Size & $-0.007(0.021)$ & $0.013(0.018)$ & $-0.018 * \star(0.007)$ \\
\hline Risk & $-0.006 * \star(0.003)$ & $-0.005 * \star(0.002)$ & $-0.000(0.001)$ \\
\hline Constant & $0.842 \star \star \star(0.077)$ & $0.738 * \star \star(0.066)$ & $0.087 \star \star \star(0.025)$ \\
\hline \multicolumn{4}{|l|}{ R-Square } \\
\hline Within & 0.157 & 0.193 & 0.061 \\
\hline Between & 0.047 & 0.057 & 0.289 \\
\hline Overall & 0.039 & 0.059 & 0.004 \\
\hline Wald test (prob.) & 0.000 & 0.000 & 0.000 \\
\hline Hausman test (prob.) & 0.000 & 0.000 & 0.000 \\
\hline No of Observ. & 905 & 905 & 905 \\
\hline Time Dummies & Yes & Yes & yes \\
\hline
\end{tabular}

Source: Author's calculation based on data from the financial statements of the sampled firms

Notes: Heteroskedasticity consistent asymptotic robust standard errors are given in parentheses. Wald $l$ is a Wald test of the joint significance of estimated coefficients, asymptotically distributed as $\chi 2$ (df) under the null of no relationship. *, **, and $\star \star \star$ indicate that coefficients are significant at the $10 \%, 5 \%$, and $1 \%$ levels, respectively. The discrepancy in the number of observations to 905 is as a result of the few missing observations and the methodological definitions adopted to construct the business risk and the growth opportunity variables.

Some specification tests undertaken to examine the efficiency of the model are: ( 1 ) the Sargan's test, which provides proof that the over-identifying restrictions on models $1,2 \& 3$ are valid; (2) the first- and second-order tests for autocorrelation of the residuals, which leads to our failing to reject the null hypothesis of no serial correlation; (3) Wald 1 tests that confirmed that the estimated coefficients are jointly significant. Table 4 contains the results of the specification tests and the system-GMM estimations, based on equation (3). For all of the models 1,2 and 3 , the coefficients of the lagged financial leverage variable are positive and unity, which suggests that Nigerian firms indeed have target leverage ratios. The adjustment speed for both total and short-term debt ratios is roughly $50 \%$ per year $(p<.000)$, whereas the adjustment speed for long-term debt is higher at about $62 \%$ per year $(p<.000)$. This implies that more than $50 \%$ of the deviation of actual total debt ratio from its optimal level and $60 \%$ of the deviation of actual long-term debt ratio can be eliminated within a year.

On the main determinant variable, the system dynamic estimation confirms the fixed effects results earlier reported. It shows that the profitability coefficient (and the coefficient of its lag variable) is negative and significant $(p<.000)$ in models 1 and 2 , but positive and nonsignificant in model 3 . This implies that in the Nigerian context, profitability plays a significant 
role in determining total debt (and short-term debt in particular), but not in determining longterm debt. This result confirms the prediction of the pecking order theory and the earlier findings of Chen (2004), Fama and French (2002), Rajan and Zingales (1995), Hansen and Crutchely (1990), and Titman and Wessels (1988). In line with the pecking order theory, more profitable firms rely on internally generated cash-flows to finance their operations, and can move on to financial sources with shorter maturity periods when the former are exhausted (Myers \& Majluf, 1984). Under this theory, it is expected that a firm should exhaust short-term debt options before issuing long-term debt (Frank \& Goyal, 2009). The Nigerian case therefore reveals that firms operating in an unstable business environment have the tendency to use short-term debt finances to augment shortfalls in their cash-flows. By extension, low earnings ratios and unstable cash-flows might be responsible for the heavy reliance on short-term debt financing in most developing countries, as found by Booth et al. (2001). The result gives an indication that in the case of Nigeria, the pecking order theory holds under the fixed and the dynamic assumptions of capital structure models.

Turning to the control variables, tangibility is found to have significant and positive effect only on long-term debt, suggesting that firms' access to the long-term market for corporate debt is indeed dependent on their levels of investment in tangible assets. This finding compares favourably with Frank and Goyal (2009), Rajan and Zingales (1995), and Braun and Larrain (2005). It is thus not unusual for lenders to insist on collateral in a country like Nigeria, which is characterised by inefficiencies in the financial system and the business operating environment. The result is also partially consistent with the prediction of the trade-off theory, which states that firms with higher investments in fixed assets have lower agency and transaction costs of debts, because such assets are more easily valued by outside investors and lenders. The fact that tangibility significantly affects long-term debt (but not total or short-term debt) explains why researchers who use data from developed countries where firms make higher proportionate use of long-term financing are quick to conclude that the relationship between tangibility and financial leverage is generally positive and highly significant.

Contrary to the findings of Rajan and Zingales (1995) as well as Booth et al., (2001), this study finds no evidence to show that size is an important determinant of financial leverage in Nigeria. This contradiction confirms the current empirical debate surrounding the real effect of size on leverage. The coefficient of risk is also confirmed to be negative and significant only in models 1 and 2 - indicating the risk-averse nature of Nigerian firms in their use of total and short-term debts. Consistent with the findings of Chakraborty (2010) and Fama and French (2002), we find a negative and significant effect of growth opportunity on total debt and short-term debt financing (and not on long-term debt financing). Consistent with the explanation offered by Chakraborty (2010) in the case of India, the result indicates that due to the reluctance of creditors to lend for long-term periods, Nigerian listed firms make extensive use of short-term debts to meet their various financing needs. Table $\mathbf{5}$ shows that long-term debt and bond issues are rarely used to finance corporate growth in Nigeria, and that external equity dominated the entire capital issues in the country's capital market between 1990 and 2003. Given the persistent financial market frictions and undeveloped bond markets in the country, it is possible that listed firms that could not access the external equity market fall back on short-term debts, even in terms of financing their long-term investment needs. 
TABLE 4: System-GMM Estimation results

\begin{tabular}{|c|c|c|c|}
\hline & $\begin{array}{c}\text { Total Debt } \\
\text { (1) }\end{array}$ & $\begin{array}{c}\text { Short-term Debt } \\
\text { (2) }\end{array}$ & $\begin{array}{c}\text { Long-term Debt } \\
\text { (3) }\end{array}$ \\
\hline \multicolumn{4}{|l|}{ Variables } \\
\hline$(1-\alpha)$ & $0.508 * * *(0.063)$ & $0.051 * * *(0.075)$ & $0.380 * * \star(0.138)$ \\
\hline Profitability & $-0.276 \star \star \star(0.115)$ & $-0.225 \star \star \star(0.091)$ & $0.020(0.059)$ \\
\hline Profitability & $-0.130 *(0.050)$ & $-0.116(0.080)$ & $0.060(0.058)$ \\
\hline Tangibility & $-0.065(0.108)$ & $-0.097(0.125)$ & $0.165 * \star(0.086)$ \\
\hline Tangibility & $-0.004(0.077)$ & $-0.101(0.069)$ & $0.109 * \star \star(0.041)$ \\
\hline Growth 0pp. & $-0.000 * \star \star(0.001)$ & $-0.000 * \star \star(0.001)$ & $0.001(0.001)$ \\
\hline Size & $-0.003(0.020)$ & $-0.010(0.016)$ & $0.007(0.008)$ \\
\hline Risk & $-0.005 * \star(0.002)$ & $-0.005 * \star(0.002)$ & $-0.001(0.001)$ \\
\hline Constant & $0.433 \star \star \star(0.136)$ & $0.502 \star \star \star(0.109)$ & $-0.102(0.057)$ \\
\hline Sargan & $57.59(0.856)$ & $58.92(0.824)$ & $56.12(0.886)$ \\
\hline $\operatorname{AR}(1)$ & $-3.353(0.001)$ & $-3.794(0.000)$ & $-2.062(0.040)$ \\
\hline $\operatorname{AR}(2)$ & $0.570(0.569)$ & $0.383(0.701)$ & $-0.553(0.581)$ \\
\hline Wald 1 & $201.23(0.000)$ & $264.67(0.000)$ & $96.24(0.000)$ \\
\hline No of Observations & 704 & 704 & 704 \\
\hline No. of Instruments & 83 & 83 & 83 \\
\hline Time Dummies & yes & yes & yes \\
\hline
\end{tabular}

Source: Author's calculation based on data from the financial statements of the sampled firms

Notes: Heteroskedasticity consistent asymptotic robust standard errors are given in parentheses. $\operatorname{AR}(1)$ and $\operatorname{AR}(2)$ are the first- and second-order autocorrelations of residuals and are asymptotically distributed as $N(0,1)$. Wald 1 is a Wald test of the joint significance of estimated coefficients, asymptotically distributed as $\chi 2(\mathrm{df})$ under the null of no relationship. Sargan's test is a test of the over-identifying restrictions, asymptotically distributed as $\chi 2$ (df) under the null of the instruments' validity. ${ }^{*}, * \star$, and $* \star *$ indicate that coefficients are significant at the $10 \%, 5 \%$, and $1 \%$ levels, respectively. 
TABLE 5: Summary of issue capital issues in the Nigerian capital market

\begin{tabular}{ccccc}
\hline & $\begin{array}{c}\text { Government } \\
\text { Securities }\end{array}$ & Corporate Bonds & Equities & Total New /ssues \\
\hline 1990 & 0.00 & 9.85 & 90.15 & 100.00 \\
1991 & 0.00 & 34.33 & 65.67 & 100.00 \\
1992 & 3.02 & 18.06 & 78.92 & 100.00 \\
1993 & 1.14 & 14.54 & 84.32 & 100.00 \\
1994 & 0.00 & 33.77 & 66.23 & 100.00 \\
1995 & 0.00 & 11.65 & 88.35 & 100.00 \\
1996 & 0.00 & 0.26 & 99.74 & 100.00 \\
1997 & 0.00 & 3.22 & 96.78 & 100.00 \\
1998 & 0.00 & 2.46 & 97.54 & 100.00 \\
1999 & 0.23 & 1.66 & 98.11 & 100.00 \\
2000 & 26.15 & 40.68 & 33.17 & 100.00 \\
2001 & 0.00 & 12.15 & 87.85 & 100.00 \\
2002 & 32.63 & 8.97 & 58.39 & 100.00 \\
2003 & 83.30 & 0.36 & 16.34 & 100.00 \\
Average & 10.46 & 13.71 & 75.83 & 100.00 \\
\hline
\end{tabular}

Source: Nigeria Securities and Exchange Commission Statistical and Economic Bulletin

\section{CONCLUSION AND POLICY IMPLICATIONS}

The purpose of this study was to investigate the impact of profitability on the financial leverage of firms operating in an unstable macroeconomic environment such as Nigeria. Specifically, the study examines the underlining assumptions of the pecking order theory that firms are at liberty to choose their financing options based only on cost and risk considerations. It finds results consistent with both fixed and dynamic panel models that the profitability of a firm is negatively and significantly related to total debt ratio. In the case of Nigeria, where over $90 \%$ of the total debt is made up of short-term debt, the study does not find any significant impact of profitability on long-term debt. The coefficient of the lagged profitability variable is also barely significant for the total debt ratio and non-significant for both the short-term and long-term debt ratios, suggesting that in Nigeria the pecking order prediction does not follow any systematic adjustment process towards the target. More specifically, though, firms operating in Nigeria do have target leverage, but they also apply different policies in adjusting towards targets, depending on the maturity of the debt instruments involved. For instance, the adjustment speed per year for total debt ratio is $50 \%$, whereas that of long-term debt is $60 \%$.

Short-term debts and external equity dominate the financial structures of Nigerian firms. Retained earnings may be unpopular because of the prevalence of the unstable business environment in the country. The arising policy implications are therefore that listed firms, in a country with the twin problems of poor corporate performance and financial market inefficiency, have less access to both internal capital and long-term debt, and that majority of firms rely more on short-term debt to finance non-growth needs and on equity to finance growth needs. This means that the relative advantage of long-term debts over external equity, as predicted by the pecking order theory, is not given any significant consideration by listed firms in Nigeria. It 
follows that, due to the nature of corporate capital structure in such economies, the cost of investment finance might be significantly higher than is the case in developed and emerging economies, where the major challenge might not border much on the efficiency of the financial markets. Firms operating in Nigeria should therefore focus policy efforts on how to manage the high cost of financing and the likelihood of bankruptcy risks associated with using short-term debts to finance growth needs. One way of resolving this challenge is for the firms to invest more in tangible assets that are acceptable as collateral for long-term finances. This recommendation is in line with our finding that asset tangibility has a positive and highly significant effect on long-term debt.

Future researchers would have to compare capital structure determinants across firms in subSaharan African countries to see if the Nigerian case is common in the region. An example would be to compare corporate financial leverage decisions in Nigeria and South Africa, given that the macroeconomic environment in the latter is almost the opposite of the Nigerian case. It is also important to point out some limitations of this study. First, small sample bias due to the data availability problem could make it difficult for any meaningful interpretation of the stability and consistency of the impact of profitability on leverage over time. This is so given that the economic situation upon which the study is premised is not constant. As shown in Figure l above, it is clear that Nigerian firms enjoyed relative earnings stability up until 1995. Hence, we expect that as more and more data becomes available on firms' performance, future studies can focus on in-depth studies on the dynamic nature of capital structure decisions in the country and in Africa as a whole.

\section{Acknowledgement}

This study was undertaken as part of the author's postdoctoral research activities at Rhodes University, South Africa. Sponsorship from the Andrew Mellon Foundation is gratefully acknowledged. The paper also benefited immensely from the comments of the participants in the Value 2010 Conference and from the rich recommendations of anonymous reviewers. Any remaining errors are the author's.

\section{LIST OF REFERENCES}

Allen, D.E. (1991). The determinants of the capital structure of listed Australian companies: the financial manager's perspective. Australian Journal of Management, 16(2), pp.103-128.

Antoniou, A., Guney, Y. \& Paudyal, K. (2008). The determinants of capital structure: capital marketoriented versus bank-oriented institutions. Journal of Financial and puantitative Analysis, 43(1), pp. 59-92.

Arellano, M. \& Bover, 0. (1995). Another look at instrumental variable estimation of errorcomponents models. Journal of Econometrics, 68 (1995), pp.29-51.

Arellano, M. \& Bond, S. (1991). Some tests of specification for panel data: Monte Carlo evidence and an application to employment equations. Review of Economic Studies, 58(2), pp. 277-297.

Arnold, G. (1998). Corporate financial management. Harlow: Financial Times and Prentice-Hall Baker, M. \& Wurgler, J. (2002). Market timing and capital structure. The Journal of Finance, 57(1), pp. $1-32$. 
Baral, K.J. (2004). Determinants of capital structure: a case study of listed companies of Nepal. The Journal of Nepalese Business Studies, 1(1), pp.1-13.

Barclay, M.J. \& Smith, C.W. (2005). The capital structure puzzle: the evidence revisited. Journal of Applied Corporate Finance, 17(1), pp. 8-18.

Baskin, J. (1989). An empirical investigation of the pecking order hypothesis. Financial Management, 18(1), pp. 26-35.

Bevan A.A. \& Danbolt, J. (2002). Capital structure and its determinants in the UK - a decomposition analysis. Applied Finance Economics, 12(3), pp.159- 70.

Blundell, R. \& Bond, S. (1998). Initial conditions and moment restrictions in dynamic panel data models. Journal of Econometrics, 87(1), pp. 115-143.

Booth, L., Aivazian, V., Demirguc-Kunt, A. \& Maksimovic, V. (2001). Capital structure in developing countries. The Journal of Finance, 56(1), pp. 87-130.

Braun, M. \& Larrain, B. (2005). Finance and the business cycle: international, inter-industry evidence. The Journal of Finance, 60 (3), pp. 1097-1128.

Chakraborty, I. (2010). Capital structure in an emerging stock market: the case of India. Research in International Business and Finance, 24(3), pp. 295-314.

Chen, J.J. (2004). Determinants of capital structure of Chinese listed companies. Journal of Business Research, 57(12), pp. 1341-1351.

Cosh, A. \& Hughes, A. (1994). Financial structure and profitability: UK companies in the 1980s. In: Hughes, A. \& Storey, D.J. (eds). Finance and the Small Firm. London: Routledge (pp. 19-63).

Demirguc-Kunt, A. \& Maksimovic, V. (1996). Stock market development and corporate finance decisions. Finance and Development, 33(2), pp. 47-49.

De Miguel, A. \& Pindado, J. (2001). Determinants of capital structure: new evidence from Spanish panel data. Journal of Corporate Finance, 7(1), pp. 77-99.

Dittmar, A. (2004). Capital structure in corporate spin-offs. Journal of Business, 77(1), pp. 9-43.

Donaldson, G. (1961): Corporate Debt Capacity: A Study of Corporate Debt Policy and the Determination of Corporate Debt Capacity, Working Paper, Harvard Business School, Harvard.

Erickson, S.M. \& Trevino, R. (1994). A pecking order approach to leasing: the airline industry case. Journal of Financial and Strategic Decisions, 7(3), pp. 71-81.

Ezeoha, A.E. \& Amaeshi, K. (2010). Banking system development, small businesses and minority lending in Nigeria. International Journal of Financia/ Services Management, 4(4), pp. 281-297.

Ezeoha, A.E. (2007). Structural effects of banking industry consolidation in Nigeria. Journal of Banking Regulation, 8(2), pp. 159-76.

Fama, E.F. \& French, K.R. (2002). Testing trade-off and pecking order predictions about dividends and debt. Review of Financial Studies, 15(1), pp. 1-33.

Flannery, M.J. \& Hankins, K.W. (2010). Estimating dynamic panel models in corporate finance. University of Florida, United States of America. (Discussion Paper)

Ferri, M.G. \& Jones, W.H. (1979). Determinants of financial structure: a new methodological approach. The Journal of Finance, 34(3), pp. 631-644. 
Frank, M. \& Goyal, V.(2009). Capital structure decisions: Which factors are reliably important? Financial Management, 38(1), pp. 1-37.

Guad, P., Jani, E., Hoesli, M. \& Bender, A. (2005). The capital structure of Swiss companies: an empirical analysis using dynamic panel data. European Financial management, 11(1), pp. 51-69.

Gomes, J.F. (2001). Financial investment. American Economic Review, 91(5), pp.1263-1285.

Gwatidzo, T. \& 0jah, K. (2009). Corporate capital structure determinants: evidence from five African countries. The African Finance Journal, 11 (1), pp. 1-23.

Hansen, R.S. and Crutchley, C. (1990). Corporate earnings and financing: an empirical analysis. Journal of Business, 63(3), pp. 347-371.

Hausman, J.A., (1978). Specification tests in econometrics. Econometrica, 46(6), pp. 1251-1271.

Huang, S.G.H. \& Song, F.M. (2006). The determinants of capital structure: Evidence from China. China Economic Review, 17, pp. 14-35.

Huynh, K. \& Petrunia, K.P. (2010). Age effects, leverage and firm growth. Journal of Economic Dynamics and Control, 34(5), pp. 1003-1013.

King, R.G. \& Ross, L. (1993). Finance, entrepreneurship and growth: theory and evidence. Journal of Monetary Economics, 32(3), pp. 513-542.

Loderer, C. \& Waelchli, U. (2009). Firm Age and Performance, European Corporate Governance Institute, Finance Working Paper No. 230/2009, Genova, Italy

Mackie-Mason, J.K. (1990). Do taxes affect corporate financing decisions? The Journal of Finance, 45(5), pp. 1471-1493.

Mako, W.P. (2001), Corporate restructuring in East Asia: promoting best practices. IMF Finance and Development, Issue 38.

Miguel, A., \& Pindado, J. (2001). Determinants of capital structure: New evidence from Spanish panel data. Journal of Corporate Finance, 7(1), pp. 77-99.

Myers, S. (1977). Determinants of corporate borrowing. Journal of Financial Economics, 5(2), pp. 147-175.

Myers, S.C. \& Majluf, N.S. (1984). Corporate financing and investment decisions when firms have information that investors do not have. Journal of Financial Economics, 13(2), pp. 187-221.

Ozkan, A. (2001): Determinants of capital Structure and Adjustment to Long Run Target: Evidence from UK Company Panel Data. Journal of Business Finance and Accounting, 28(182), pp. 175-198.

Pandey, M. (2004). Capital structure, profitability and market structure: evidence from Malaysia. Asia Pacific Journal of Economics and Business, 8(2), pp. 78-89.

Rajan, G.R. \& Zingales, L. (1995). What do we know about capital structure? Some evidence from international data. The Journal of Finance, 50(5), pp. 1421-1460.

Schoubben, F. \& Van Hulle, C. (2004). The determinants of leverage: differences between quoted and non quoted firms. Trijdschrift voor Economie en Management, 49(4), pp. 589-620.

Shyam-Sunder, L., \& Myers, S.C., (1999). Testing static trade-off against pecking order models of capital structure. Journal of Financial Economics, 51(2), pp. 219-244.

Stein, J. C. (1997). Internal capital markets and the competition for corporate resources. The Journal of Finance, 52(1) pp. 111-133. 
Titman, S. \& Wessels, R. (1988). The determinants of capital structure. Journal of Finance, 43(1), pp. 209-243.

Toy, N., Stonehill, A., Remmers, L., Wright, M.R. \& Beekhuisen, T. (1974). A comparative international study of growth, profitability, and risk as determinants of corporate debt ratios in the manufacturing sector. Journal of Financial and Puantitative Analysis, 9(5), pp. 875-886. 